\title{
Terfezia solaris-libera sp. Nov., A New Mycorrhizal Species within the Spiny-Spored Lineages
}

\author{
Louro $\mathbf{R}^{1 *}$, Nobre $\mathrm{T}^{1}$ and Santos Silva $\mathrm{C}^{2}$ \\ ${ }^{1}$ Mediterranean Institute for Agriculture, Environment and Development, Portugal \\ ${ }^{2}$ Department of Biology, Mediterranean Institute for Agriculture Environment and \\ Development, Portugal
}

*Corresponding author: Rogério Louro, Mediterranean Institute for Agriculture, Environment and Development, University of Evora, Apartado, Portugal, Tel: 947002554; Email: rlouro@uevora.pt

\section{Research Article}

Volume 3 Issue 1

Received Date: April 01, 2020

Published Date: April 30, 2020

DOI: $10.23880 /$ oajmms-16000121

\section{Abstract}

A new Terfezia species-Terfezia solaris-libera sp. nov., associated with Tuberaria guttata (Cistaceae) is described from Alentejo, Portugal. T. solaris-libera sp. nov. distinct morphology has been corroborated by its unique ITS-rDNA sequence. Macro and micro morphologic descriptions and phylogenetic analyses of ITS data for this species are provided and discussed in relation to similar spiny-spored species in this genus and its putative host plant Tuberaria guttata. T. solaris-libera sp. nov. differs from other spiny-spored Terfezia species by its poorly delimited and thicker peridium and distinct spore ornamentation, and from all Terfezia spp. in it's ITS nrDNA sequence. In comparison, T. fanfani usually reach large ascocarp dimensions, often with prismatic peridium cells, with olive green tinges in mature gleba and different spore ornamentation. T. lusitanica has a lighter yellowish and thinner peridium and a blackish gleba upon maturity, T. extremadurensis has a thinner well delimited peridium and Tuber-like gleba and T. cistophila has a spermatic odour and is exclusively associated with Cistus spp.

Keywords: Desert Truffle; Hypogeous; Ascomycota; Pezizaceae; Cistaceae; Tuberaria Guttata; Portugal

Abbreviations: ITS: Internal Transcribed Spacer; MCMC: Markov Chain Monte Carlo; ML: Maximum Likelihood; ME: Minimum Evolution; NJ: Neighbor-Joining; AIC: Akike information criterion; MCL: Maximum Composite Likelihood; CNI: Close-Neighbor-Interchange.

\section{Introduction}

Terfezia species are ectomycorrhizal desert truffles (Ascomycota, Pezizales), found in arid and semi-arid environments, around the Mediterranean basin. Most Terfezia species establish mycorrhizal symbiosis with perennial and annual plants belonging to Cistaceae, mainly with Helianthemum species in alkaline soils [1-5] and with Tuberaria guttata (L.) Four and its subspecies and varieties, in acid soils [6-8], many Terfezia species are endemic and overall play an essential role in soil conservation -preventing erosion and desertification-in Mediterranean shrublands and xerophytic grasslands [9]. The genus Terfezia (Tul. and C.Tul.). Is undoubtedly the most specious desert truffle genus [10], with a great number of novel species being described every year [11], Morphological, ecological and chemical features, often ambiguous, are still the main criteria for separating and/or identifying groups of species [12]. For instance, one of the most solid criteria for discriminating all known Terfezia species is spore morphology. Yet, and without molecular techniques, is nowadays almost impossible to separate most spiny-spored Terfezia beyond doubt.

Currently, the described spiny spored Terfezia species 


\section{Open Access Journal of Mycology \& Mycological Sciences}

exclusively associated to T. guttata in acid soils are T. fanfani Mattirolo O, et al. [13], T. extremadurensis Bordallo J, et al. [6] and T. lusitanica Bordallo J, et al. [14]. The present study describes a new spiny spored Terfezia species in association with T. guttata in sandy acid soils, found in Alentejo (Portugal). Furthermore, a specimen belonging to $T$. cistophila was also found and here reported as a new record for Portugal.

\section{Methods}

\section{Fungal Collections and Collecting Sites}

Terfezia ascocarps were collected in different years and from different locations in Centre and Southern Portugal. Throughout the collection period (from February to April), fresh specimens were brought to the laboratory for morphological and molecular characterization. The putative plant host was registered and soil samples were collected nearby each specimen. Fragments of each specimen were frozen at $20^{\circ} \mathrm{C}$ for DNA amplification and the remaining specimen were dried at $40^{\circ} \mathrm{C}$ and stored in sealed plastic bags, labeled with collection details. All samples are deposited at the Herbarium of the Evora University Herbarium (UEVHFUNGI), Portugal. Soil samples (50 mm diam., $150 \mathrm{~mm}$ depth) were collected in each collection site. A compose sample of 6 soil samples replicas per site was made and analyzed at the Laboratório Químico Agrícola Rebelo da Silva (INIAV/LQARS) for particle size and subsequent soil textural classification and water $\mathrm{pH}$ measurements [15].

\section{Morphological Study}

External ascocarp characteristics (shape, colour, appearance) were in detail recorded from fresh specimens. Ascocarps were then cut and the morphology of the peridium and gleba was described. Microscopic observations were performed in distilled water, $\mathrm{KOH} \mathrm{5 \%}$ and Melzer's reagent. Spores dimensions are based on a minimum of 100 randomly selected spores outside asci. Peridium of dried specimens were rehydrated and examined in $\mathrm{KOH} \mathrm{5 \%}$. Melzer's reagent was used to test the amyloidity of asci, spores and tissues. Asci and ascospores were examined using a Leica DM750 microscope equipped with a digital camera (Leica ICC50 W). For identification, ascomata were compared with the descriptions from Bordallo, et al. $[6,7,14]$ and Mattirolo, et al. [13].

\section{DNA Amplification and Sequencing}

DNA extraction from the analyzed specimen was performed by CTAB method, following the protocol described in Nobre, et al. [16]. All extraction products were stored at $-20^{\circ} \mathrm{C}$ and later used directly in the PCR. The Internal Transcribed Spacer (ITS) region of the rDNA, including the 5.8S ribosomal gene, was amplified using the ITS5 and ITS4 primers [17]. PCR reactions were conducted using $1 \mu \mathrm{l}$ of the extracted DNA in a standard $25 \mu \mathrm{l}$ reaction, with $0.5 \mathrm{pmol} / \mu \mathrm{l}$ of each primer, $1.5 \mathrm{mM} \mathrm{MgCl} 2,0.5 \mathrm{mM}$ dNTPs and $0.04 \mathrm{U} / \mathrm{ml}$ Taq DNA polymerase. PCR reactions were performed using a Mastercycler Gradient thermocycler (Eppendorf, Hamburg, Germany) with the following cycling parameters: an initial denaturalization step for $3 \mathrm{~min}$ at $95^{\circ} \mathrm{C}$, followed by 35 cycles consisting of: $30 \mathrm{~s}$ at $95^{\circ} \mathrm{C}, 30 \mathrm{~s}$ at $95^{\circ} \mathrm{C}$ (annealing temp.), $1 \mathrm{~min}$ at $72^{\circ} \mathrm{C}$, and a final extension at $72^{\circ} \mathrm{C}$ for $10 \mathrm{~min}$. All the PCR products were purified using the NZYGelpure kit (from NZYTech, Lda) and sequencing was done commercially (STAB VIDA, Lda.).

\section{Phylogenetic Analysis}

The final dataset comprised 78 Terfezia ITS sequences (Table 1, Supplemental Table 1) and a Tirmania nivea specimen as out group (FN395015). Additional to the sequences pertaining the collected specimens, the dataset comprised 3 representative sequences from each Terfezia clade previously identified and described [11]. Care was taken to always include the Terfezia species type sequence as deposited in the comprehensive database Gen Bank All sequences were assembled, edited and aligned with online MAFFT version 7, using the E-INS-i strategy [18]. The phylogenetic reconstruction analysis based on the above ITS sequences was performed in BEAST v.4.2.8 software [19], allowing the software to estimate the evolutionary model. All other settings were left as default. Three independent Markov Chain Monte Carlo (MCMC) runs, starting from randomly chosen topologies were performed as a safeguard against spurious results. The MCMC were run for 10,000,000 generations with data sampled every 1,000 generations. Logfile outputs were inspected in Tracer v.1.6 to determine chain convergence and burnin. The first $10 \%$ of the generations were discarded as the burn-in, the tree-file outputs from individual MCMC runs were combined in Log Combiner v.2.4.8. And the maximum clade credibility tree and corresponding posterior probabilities were obtained using Tree Annotator v.2.4.8 [19]. To test the congruence between methods, reconstructions with Maximum Likelihood (ML), Minimum Evolution (ME) and Neighbor-Joining (NJ) methods were performed in Mega 10.0.5 [20]. The best-fit nucleotide substitution model was selected with the program Model Test [21] applying the Akike information criterion (AIC) and this information was used to calculate the distances in the MLanalysis. 


\section{Open Access Journal of Mycology \& Mycological Sciences}

\begin{tabular}{|c|c|c|c|c|c|c|}
\hline Species & GenBank & Voucher No. & Collection Date & Collection Site (Portugal) & Plant Host & Soil Type \\
\hline T. cistophila & MN338749 & 2004068 & $20 / 04 / 2018$ & Alentejo, Évora & Cistus salviifolius & Loamy sand, pH 5.6 \\
\hline \multirow{7}{*}{ T. lusitanica } & MN338748 & 2004668 & $22 / 03 / 2019$ & Lisboa, Alcochete & Tuberaria guttata & Sandy soils, pH 6.1 \\
\hline & MG818754 & 2003876 & $20 / 04 / 2017$ & Alentejo, Montemor- o-Novo & T. guttata & Loamy sand, pH 5.5 \\
\hline & MN338747 & 2004669 & $22 / 03 / 2019$ & Lisboa, Alcochete & T. guttata & Sandy soils, pH 6.1 \\
\hline & MN338745 & 2003487 & $20 / 04 / 2016$ & Alentejo, Montemor- o-Novo & T. guttata & Loamy sand, pH 5.5 \\
\hline & MN338744 & 2003442 & $24 / 04 / 2016$ & Alentejo, Mora & T. guttata & Loamy sand, pH 5.7 \\
\hline & MN338746 & 2004677 & $22 / 03 / 2019$ & Lisboa, Alcochete & T. guttata & Sandy soils, pH 6.1 \\
\hline & MG818752 & 2003065 & $03 / 04 / 2012$ & Alentejo, Montemor- o-Novo & T. guttata & Loamy sand, pH 5.5 \\
\hline \multirow{10}{*}{ T. fanfani } & MN338740 & 2004051 & $22 / 03 / 2018$ & Alentejo, Évora & T. guttata & Sandy loam, pH 6.2 \\
\hline & MN338738 & 2004078 & $20 / 04 / 2018$ & Alentejo, Évora & T. guttata & Loamy sand, pH 5.6 \\
\hline & MN338742 & 2004680 & $20 / 03 / 2019$ & Alentejo, Ponte de Sor & T. guttata & Loamy sand, pH 5.7 \\
\hline & MN338734 & 2003847 & $30 / 03 / 2017$ & Alentejo, Arraiolos & T. guttata & Sandy loam, pH 6.0 \\
\hline & MN338741 & 2004664 & 02/03/2019 & Alentejo, Évora & T. guttata & Sandy loam, pH 6.2 \\
\hline & MN338735 & 2004054 & $22 / 03 / 2018$ & Alentejo, Évora & T. guttata & Sandy loam, pH 6.2 \\
\hline & MN338736 & 2004058 & $22 / 03 / 2018$ & Alentejo, Évora & T. guttata & Sandy loam, pH 6.2 \\
\hline & MN338737 & 2004087 & $25 / 04 / 2018$ & Alentejo, Arraiolos & T. guttata & Sandy loam, pH 6.0 \\
\hline & MN338739 & 2004088 & $25 / 04 / 2018$ & Alentejo, Arraiolos & T. guttata & Sandy loam, pH 6.0 \\
\hline & MN338743 & 2004678 & $22 / 03 / 2019$ & Lisboa, Alcochete & T. guttata & Loamy sand, pH 5.2 \\
\hline \multirow{7}{*}{$\begin{array}{l}\text { T. solaris- } \\
\text { libera sp. }\end{array}$} & MN338731 & 2004089 & $25 / 04 / 2018$ & Alentejo, Arraiolos & T. guttata & Sandy loam, pH 6.0 \\
\hline & MN338729 & 2003820 & $30 / 03 / 2017$ & Alentejo, Arraiolos & T. guttata & Sandy loam, pH 6.0 \\
\hline & MN338730 & 2003821 & $30 / 03 / 2017$ & Alentejo, Arraiolos & T. guttata & Sandy loam, pH 6.0 \\
\hline & MN338727 & 2003840 & $30 / 03 / 2017$ & Alentejo, Arraiolos & T. guttata & Sandy loam, pH 6.0 \\
\hline & MN338728 & 2003846 & $30 / 03 / 2017$ & Alentejo, Arraiolos & T. guttata & Sandy loam, pH 6.0 \\
\hline & MN338733 & 2004593 & $27 / 02 / 2019$ & Alentejo, Évora & T. guttata & Sandy loam, pH 6.0 \\
\hline & MN338732 & 2004746 & $14 / 02 / 2019$ & Alentejo, Arraiolos & T. guttata & Sandy loam, pH 6.0 \\
\hline
\end{tabular}

Table 1: Terfezia collections analysed.

\section{Supplemental Material 1}

Totest the congruence between methods, reconstructions with Maximum Likelihood (ML), Minimum Evolution (ME) and Neighbor-Joining (NJ) methods were performed in Mega 10.0.5 Kumar, et al. [20]. Each analysis involved 79 nucleotide sequences. All ambiguous positions were removed for each sequence pair (pairwise deletion option). There were a total of 738 positions in the final dataset.

The best-fit nucleotide substitution model selected with the program jModel Test Posada, et al. [21] applying the Akaike information criterion (AIC) was GTR+I+G. This model was used to calculate the distances for the ML analysis (Figure S1). 


\section{Open Access Journal of Mycology \& Mycological Sciences}

\begin{tabular}{|c|c|c|c|c|c|c|c|}
\hline Terfezia Species & Accession № & $\begin{array}{l}\text { Seq. } \\
\text { Lenght } \\
\text { (bp) }\end{array}$ & Reference & $\begin{array}{l}\text { DNA } \\
\text { Source }\end{array}$ & Collection Site & Host Plant & $\begin{array}{l}\text { Soil } \\
\text { Type }\end{array}$ \\
\hline AF396864 & AF396864 & 600 & Diez J, et al. [22] & $\begin{array}{l}\text { Isolate/ } \\
\text { strain }\end{array}$ & Spain:Valencia & Pinus halepensis & Acid \\
\hline \multirow{3}{*}{ T. albida } & HM056220* & 631 & Bordallo J, et al. [6] & Fruitbody & Spain:Albacete & Helianthemum sp. & Alkaline \\
\hline & HM056221 & 641 & Bordallo J, et al. [6] & Fruitbody & Spain: Albacete & Helianthemum sp. & Alkaline \\
\hline & HQ698146 & 662 & Kovacs GM, et al. [23] & Fruitbody & Spain:Salamanca & Tuberaria guttata & - \\
\hline \multirow{3}{*}{ T. alsheikhii } & HM056207 & 638 & Bordallo J, et al. [6] & Fruitbody & $\begin{array}{l}\text { Portugal:Trás-os- } \\
\text { Montes }\end{array}$ & Cistaceae & Acid \\
\hline & HM056208 & 589 & Bordallo J, et al. [6] & Fruitbody & Spain:Badajoz & - & - \\
\hline & HQ698100* & 653 & Kovacs GM, et al. [23] & Fruitbody & Spain:Salamanca & Tuberaria lignosa & Acid \\
\hline \multirow{3}{*}{ Tarenaria } & HQ698066 & 655 & Kovacs GM, et al. [23] & Fruitbody & Spain:Badajoz & Quercus ilex & Acid \\
\hline & HQ698067 & 656 & Kovacs GM, et al. [23] & Fruitbody & Spain:Salamanca & Tuberaria guttata & Acid \\
\hline & KP217815 & 602 & Dafri A, et al. [24] & Fruitbody & Algeria & Tuberaria guttata & - \\
\hline \multirow{3}{*}{ T. boudieri } & AF092096 & 616 & Ferdman Y, et al. [25] & Fruitbody & Israel:Negev & - & - \\
\hline & FN395016 & 594 & Bouzadi M, et al. [26] & Fruitbody & $\begin{array}{l}\text { Libya:Hammad } \\
\text { Al Hamra }\end{array}$ & - & - \\
\hline & GU474808 & 579 & Sbissi I, et al. [27] & $\begin{array}{l}\text { Isolate/ } \\
\text { strain }\end{array}$ & Tunisia & Helianthemum sp. & - \\
\hline \multirow{3}{*}{ T. canariensis } & JQ858196 & 504 & Bordallo JJ, et al. [28] & Fruitbody & $\begin{array}{l}\text { Spain:Canary } \\
\text { Island }\end{array}$ & $\begin{array}{l}\text { Helianthemum } \\
\text { canariense }\end{array}$ & Alkaline \\
\hline & JQ858188 & 351 & Bordallo JJ, et al. [28] & Fruitbody & $\begin{array}{l}\text { Spain:Canary } \\
\text { Island } \\
\end{array}$ & $\begin{array}{l}\text { Helianthemum } \\
\text { canariense }\end{array}$ & Alkaline \\
\hline & JQ858190* & 351 & Bordallo JJ, et al. [28] & Fruitbody & $\begin{array}{l}\text { Spain:Canary } \\
\text { Island }\end{array}$ & $\begin{array}{l}\text { Helianthemum } \\
\text { canariense }\end{array}$ & Alkaline \\
\hline \multirow{3}{*}{ T. cistophila } & KP728823 & 655 & Bordallo JJ, et al. [28] & Fruitbody & Spain:Caceres & Cistus ladanifer & Acid \\
\hline & KP728824 & 611 & Bordallo JJ, et al. [28] & Fruitbody & Spain: Badajoz & Cistus ladanifer & Acid \\
\hline & KP728828* & 594 & Bordallo JJ, et al. [28] & Fruitbody & $\begin{array}{l}\text { Greece:Nea } \\
\text { Makri Attica }\end{array}$ & $\begin{array}{c}\text { Cistus monspeliensis, } C . \\
\text { creticus }\end{array}$ & Acid \\
\hline \multirow{3}{*}{ T. claveryi } & HM352540 & 634 & Jamali S. et al. [29] & $\begin{array}{l}\text { Isolate/ } \\
\text { strain }\end{array}$ & Iran & $\begin{array}{c}\text { Helianthemum sp., Carex } \\
s p .\end{array}$ & Alkaline \\
\hline & GU474801 & 608 & Sbissi I, et al. [27] & $\begin{array}{c}\text { Isolate/ } \\
\text { strain }\end{array}$ & Tunisia & $\begin{array}{c}\text { Helianthemum } \\
\text { kahiricum }\end{array}$ & Alkaline \\
\hline & HQ698080 & 658 & Kovacs GM, et al. [23] & Fruitbody & Spain:Granada & $\begin{array}{l}\text { Helianthemum } \\
\text { salicifolium }\end{array}$ & - \\
\hline \multirow{3}{*}{$\begin{array}{c}T . \\
\text { crassiverrucosa }\end{array}$} & AF387646 & 583 & Kovacs GM, et al. [23] & $\begin{array}{l}\text { Isolate/ } \\
\text { strain }\end{array}$ & Spain & - & - \\
\hline & AF387647 & 580 & Kovacs GM, et al. [23] & $\begin{array}{l}\text { Isolate/ } \\
\text { strain }\end{array}$ & Spain:Murcia & - & - \\
\hline & MF940203* & 513 & Zitouni HF, et al. [30] & $\begin{array}{c}\text { Fruitbody } \\
\text { (Holotype) }\end{array}$ & Algeria & Helianthemum sp. & Alkaline \\
\hline
\end{tabular}




\begin{tabular}{|c|c|c|c|c|c|c|c|}
\hline \multirow{3}{*}{ T. eliocrocae } & HM056205 & 627 & Bordallo J, et al. [6] & Fruitbody & Spain: Murcia & Helianthemum sp. & Alkaline \\
\hline & HM056206 & 534 & Bordallo J, et al. [6] & Fruitbody & Spain: Murcia & Helianthemum sp. & Alkaline \\
\hline & MF940200 & 547 & Zitouni HF, et al. [30] & Fruitbody & Algeria & Helianthemum lippii & Alkaline \\
\hline \multirow{3}{*}{ T. extremadurensis } & HM056199* & 544 & Bordallo J, et al. [6] & Fruitbody & Spain:Caceres & Tuberaria guttata & - \\
\hline & HM056202 & 596 & Bordallo J, et al. [6] & Fruitbody & Spain:Caceres & Tuberaria guttata & - \\
\hline & HQ698134 & 534 & Kovacs GM, et al. [23] & Fruitbody & Spain:Jaen & Cistus albidus & - \\
\hline \multirow{3}{*}{ T. fanfani } & HM056217* & 645 & Bordallo J, et al. [6] & Fruitbody & Spain: Caceres & Tuberaria guttata & Acid \\
\hline & HM056219 & 596 & Bordallo J, et al. [6] & Fruitbody & Spain:Badajoz & Tuberaria guttata & Acid \\
\hline & HQ698088 & 647 & Kovacs GM, et al. [23] & Fruitbody & Spain:Caceres & - & - \\
\hline \multirow{3}{*}{ T. grisea } & KP189328 & 655 & Bordallo JJ, et al. [28] & Fruitbody & Spain:Burgos & Helianthemum sp. & Alkalin \\
\hline & KP189330* & 590 & Bordallo JJ, et al. [28] & Fruitbody & $\begin{array}{c}\text { Greece: } \text { Schinias }_{-} \\
\text {Attica }\end{array}$ & Pinus spp. & Alkaline \\
\hline & KP189333 & 591 & Bordallo JJ, et al. [28] & Fruitbody & Spain:Burgos & Helianthemum sp. & Alkaline \\
\hline \multirow{3}{*}{ T. lusitanica } & MG818752 & 591 & Bordallo JJ, et al. [14] & Fruitbody & Portugal:Alentejo & Tuberaria guttata & Acid \\
\hline & MG818753* & 656 & Bordallo JJ, et al. [14] & $\begin{array}{l}\text { Fruitbody } \\
\text { (Holotype) }\end{array}$ & Spain:Caceres & Tuberaria guttata & Acid \\
\hline & MG818754 & 588 & Bordallo JJ, et al. [14] & Fruitbody & Portugal:Alentejo & Tuberaria guttata & Acid \\
\hline \multirow{3}{*}{ T. morenoi } & MG640480* & 539 & Crous P, et al. [31] & Fruitbody & Spain:Albacete & Pinus spp., Quercus spp. & Alkaline \\
\hline & MG640478 & 539 & Crous P, et al. [31] & Fruitbody & Spain:Albacete & Pinus spp., Quercus spp. & Alkaline \\
\hline & MG640482 & 542 & Cro & Fruitbody & Spain: La Rioja & Pinus spp., Quercus spp. & Alkaline \\
\hline \multirow{3}{*}{ T. olbiensis } & AF387657 & 569 & Kovacs GM, et al. [23] & $\begin{array}{l}\text { Isolate/ } \\
\text { strain }\end{array}$ & Spain & - & - \\
\hline & HM056225 & 628 & Bordallo J, et al. [6] & Fruitbody & Spain:Valencia & Pinus sp. & - \\
\hline & HQ698102 & 641 & Kovacs GM, et al. [23] & Fruitbody & Spain:Madrid & - & - \\
\hline \multirow{3}{*}{ T. pini } & HM056209 & 633 & Bordallo J, et al. [6] & Fruitbody & Spain:Valladolid & Pinus sp. & - \\
\hline & HM056210* & 631 & Bordallo J, et al. [6] & Fruitbody & Spain:Burgos & Pinus sp. & - \\
\hline & HQ698138 & 662 & Kovacs GM, et al. [23] & Fruitbody & Spain:Palencia & Quercus spp. & - \\
\hline \multirow{3}{*}{$\begin{array}{c}T . \\
\text { pseudoleptoderma }\end{array}$} & HM056211* & 588 & Bordallo J, et al. [6] & Fruitbody & Spain:Burgos & Cistaceae & - \\
\hline & HM056212 & 647 & Bordallo J, et al. [6] & Fruitbody & Spain:Burgos & Cistaceae & - \\
\hline & HM056213 & 631 & Bordallo J, et al. [6] & Fruitbody & Spain:Caceres & Cistaceae & - \\
\hline \multirow{3}{*}{ T. solaris-libera } & HM056215 & 628 & Bordallo J, et al. [6] & Fruitbody & Spain:Badajoz & Cistaceae & - \\
\hline & HQ698132 & 643 & Kovacs GM, et al. [23] & Fruitbody & Spain:Zamora & - & - \\
\hline & HQ698149 & 641 & Kovacs GM, et al. [23] & Fruitbody & Spain: Caceres & Cistaceae & - \\
\hline
\end{tabular}

Table S1: Terfezia collections analysed.

As to the NJ (Figure S2) and ME (Figure S3) analysis, the most simple model was assumed where evolutionary distances were computed using the p-distance method, showing the robustness of the monophyly of the groups considered as taxonomic units. 


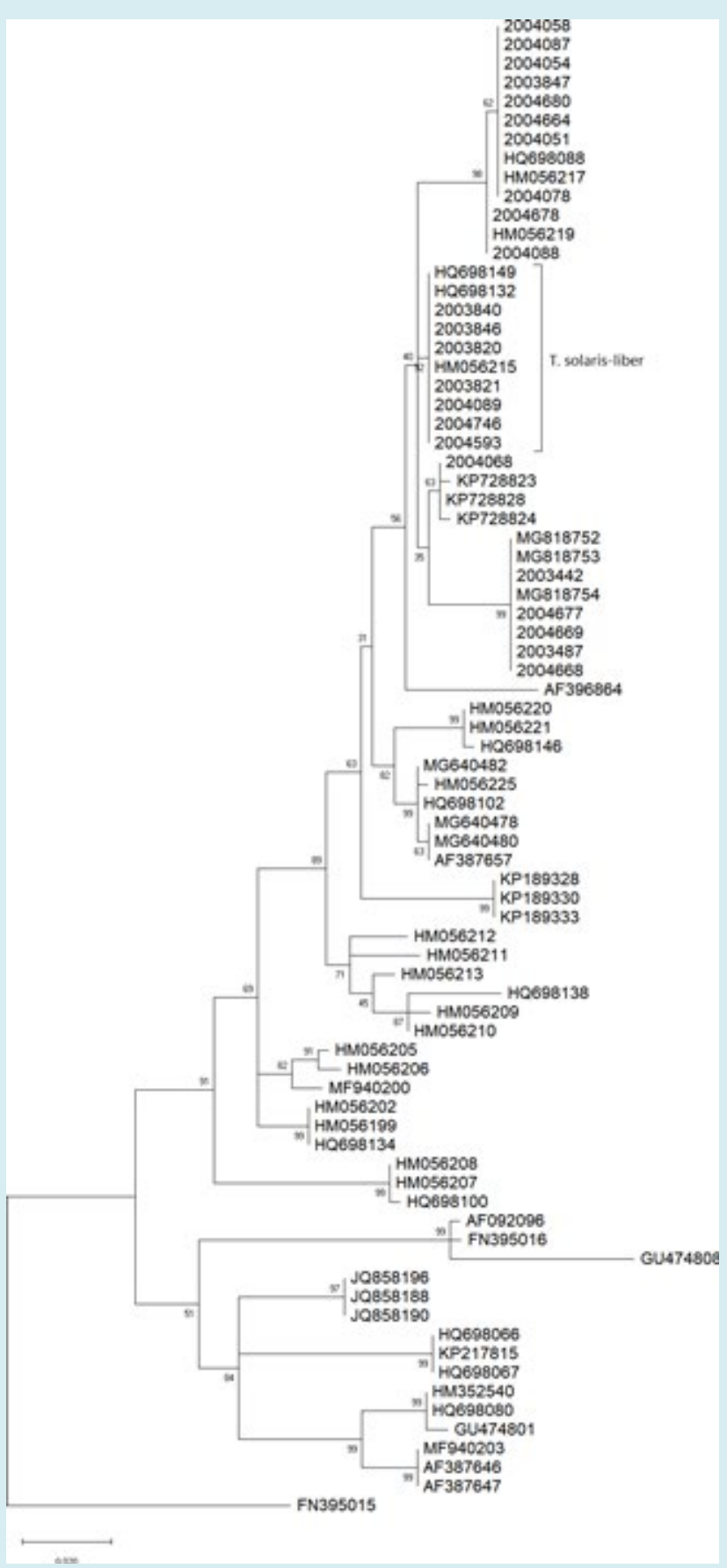

Figure S1: The relation between specimens was inferred using the Maximum Likelihood method and General Time Reversible model Nei M, et al. [32]. The tree with the highest log likelihood (-1968.39) is shown. The percentage of trees in which the associated taxa clustered together is shown next to the branches. Initial tree(s) for the heuristic search were obtained automatically by applying Neighbor-Join and BioNJ algorithms to a matrix of pairwise distances estimated using the Maximum Composite Likelihood (MCL) approach, and then selecting the topology with superior log likelihood value. The rate variation model allowed for some sites to be evolutionarily invariable ([+I], 37.13\% sites). The tree is drawn to scale, with branch lengths measured in the number of substitutions per site. All positions with less than $95 \%$ site coverage were eliminated, i.e., fewer than $5 \%$ alignment gaps, missing data, and ambiguous bases were allowed at any position (partial deletion option). 


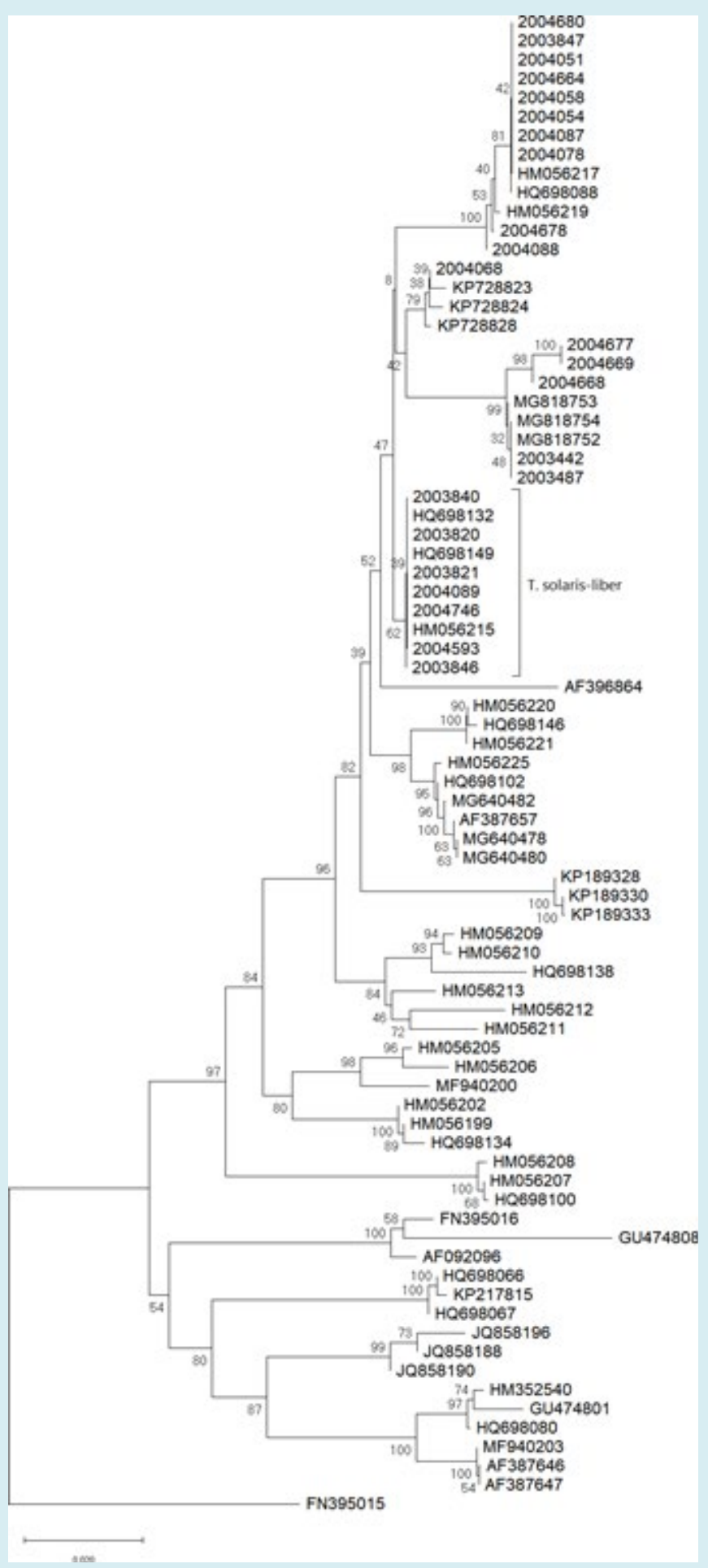

Figure S2: The relation between specimens was inferred using the Neighbor-Joining method Saitou N, et al. [33]. The optimal tree with the sum of branch length $=0.69421768$ is shown. The percentage of replicate trees in which the associated taxa clustered together in the bootstrap test (1000 replicates) are shown next to the branches Felsenstein J, et al. [34]. The tree is drawn to scale, with branch lengths in the same units as those of the evolutionary distances used to infer the phylogenetic tree. The evolutionary distances were computed using the p-distance method Nei M, et al. [32] and are in the units of the number of base differences per site. 


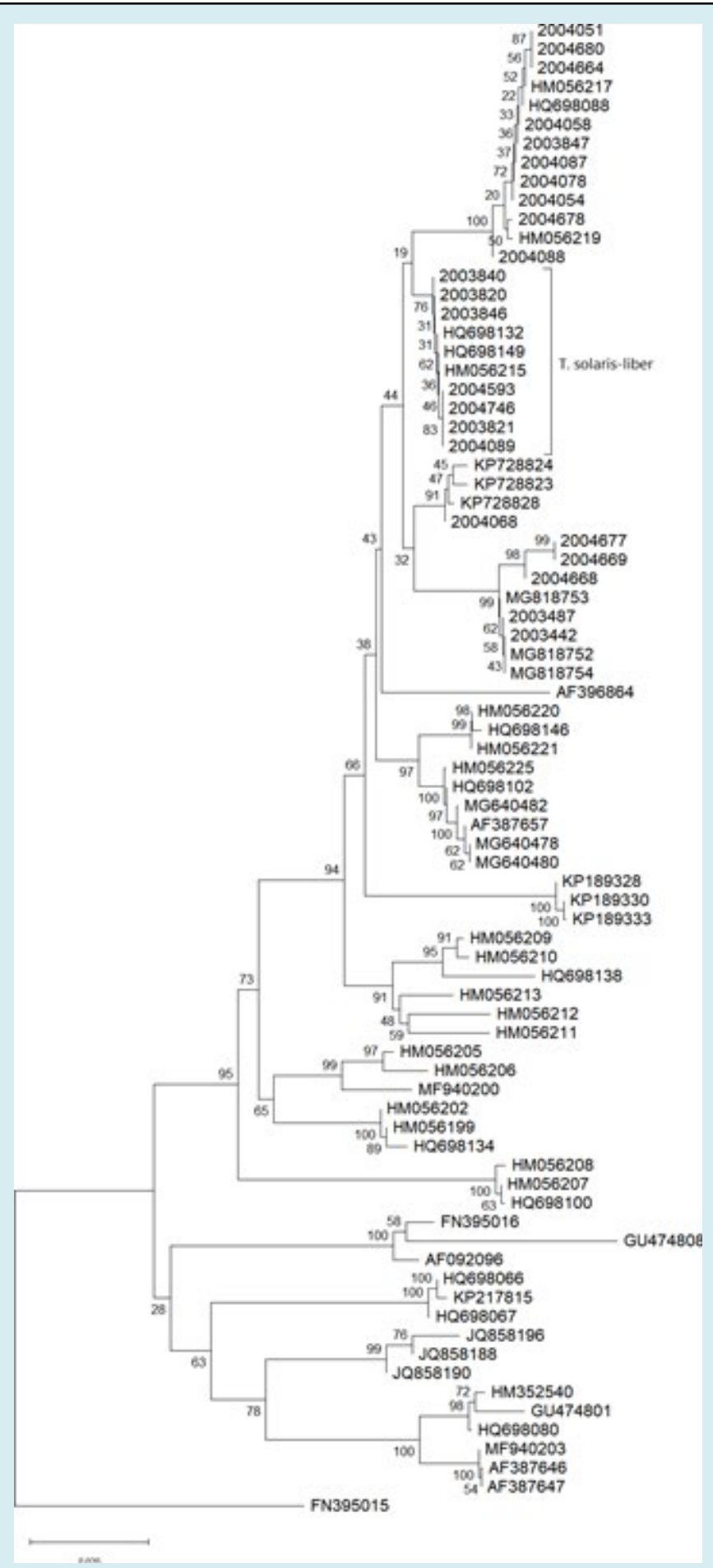

Figure S3: The relation between specimens was inferred using the Minimum Evolution method Rzhetsky A, et al. [35]. The optimal tree with the sum of branch length $=0.69543083$ is shown. The percentage of replicate trees in which the associated taxa clustered together in the bootstrap test (1000 replicates) are shown next to the branches Felsenstein J, et al. [34]. The tree is drawn to scale, with branch lengths in the same units as those of the evolutionary distances used to infer the phylogenetic tree. The evolutionary distances were computed using the p-distance method Nei M, et al. [32] and are in the units of the number of base differences per site. The ME tree was searched using the Close-Neighbor-Interchange (CNI) algorithm Nei M, et al. [32] at a search level of 1. 


\section{Open Access Journal of Mycology \& Mycological Sciences}

\section{Results}

Beside the new species described thereafter, our collections included also specimens belonging to other spiny-spored Terfezia (Table 1). Regarding soil analyses, even though not exhaustive, revealed distinct micro- ecological preferences, namely, T. lusitanica prefer sandier soils and T. solaris-libera sp. nov. less sandy soils. As for, T. fanfani, it showed a larger range of edaphic preferences, all inside the major group of sandy soils. T. cistophila, was found only once and in loamy sand soils (Table 1), nevertheless, it is worth mention since is the first reference of the species in Portugal.

\section{Taxonomy}

Name: Terfezia solaris-libera Louro, Nobre, Santos-Silva, sp. nov.

Type: PORTUGAL, Alentejo, Arraiolos, in roadside verges near grasslands areas without trees, associated exclusively with Tuberaria guttata; 25 April 2018; leg. C. Santos-Silva, Holotype: UEVH-FUNGI 2004089.

Diagnosis: Ascomata $1.5-2.5 \mathrm{~cm}$ in diam., hypogeous, subglobose and light coloured to brownish. Peridium 500$700 \mu \mathrm{m}$ thick, poorly delimited and pseudoparenchymatous composed of subglobose cells of variable size. Gleba with brownish pockets of fertile tissue surrounded by whitish, sterile, veins, becoming uniformly brownish coloured at maturity. Ascospores globose, (20-)21.6(-23) $\mu \mathrm{m}$ diam. (median=22 $\mu \mathrm{m}$ ) including ornamentation; (15) $15.7(-17) \mu \mathrm{m} \quad($ median=16 $\mu \mathrm{m})$ without ornamentation; light brown and ornamented with conical, blunt spines, sometimes cylindrical, generally straight, but sometimes slightly curved, separated, $2-3 \mu \mathrm{m}$ long, $1-1.5 \mu \mathrm{m}$ wide at the base. Terfezia solaris-libera sp. nov. Differs from other spiny-spored Terfezia species associated with Tuberaria guttata by its poor delimited thicker peridium and different sporal ornamentation, and from all Terfezia spp. in its ITS nrDNA sequence. T. fanfani usually reaches larger ascocarp dimensions, has prismatic peridium cells, olive green tinges in mature gleba and different spore ornamentation constituted by sharp thin elongated conic spines (2-)3-4(-5) $\mu$ m long; $T$. lusitanica has a lighter yellowish and thinner peridium and a blackish gleba upon maturity and finally T. extremadurensis has a thinner well delimited peridium and tuber like gleba. Exclusively associated with Cistus, Terfezia cistophila shares a similar habitat as the aforementioned species, differing from all in its spermatic odour.

Etymology: "solaris" refers to the sun, due to its particular spore ornamentation and ecology, and "libera" due to the collection date of the type (25 April, the Freedom day in Portugal which commemorates the Carnation Revolution). Description: Ascomata hypogeous, subglobose, $1.5-2.5 \mathrm{~cm}$ in diameter, light ochre colour at first, becoming darker in maturity, smooth (Figures 1A \& 1B). Faint odour, not distinctive. Mild taste. Peridium 500-700 $\mu \mathrm{m}$ thick, not separable from gleba, poorly delimited, whitish in cross section, pseudoparenchymatous, composed of subglobose cells of variable size, hyaline and thin-walled in the innermost layers (max. 40 $\mathrm{m}$ diam.), yellowish and with thicker walls in the outermost layers (max. $8 \mu \mathrm{m}$ diam.) (Figure 1C). Gleba solid, fleshy, succulent, whitish at first, then with brownish pockets of fertile tissue surrounded by whitish sterile veins, finally becoming uniformly brownish coloured at maturity (Figures 1A \& 1B). Asci no amyloid, subglobose, sessile, 65$80 \times 50-65=\mu \mathrm{m}$ diam., walls $1 \mu \mathrm{m}$ thick, with 6-8 irregularly disposed spores (Figures $1 F$ \& $1 G$ ), randomly arranged in the gleba. Ascospores. globose, (20-) 21.6(-23) $\mu \mathrm{m}$ diam. (median $=22=\mu \mathrm{m})$ including ornamentation; (15-)15.7(17) $\mu \mathrm{m}$ (median $=16 \mu \mathrm{m})$ without ornamentation; hyaline, smooth and uniguttulated at first, by maturity light brown and ornamented with conical, blunt spines, sometimes cylindrical, generally straight, but sometimes slightly curved, separated, $2-3 \mu \mathrm{m}$ long, $1-1.5 \mu \mathrm{m}$ wide at the base (Figures 1D \& $1 \mathrm{E})$.

Habitat and Distribution: Hypogeous mycorrhizal fungi, in sandy loam (80-83\% sand material), acid soils ( $\mathrm{pH} 6$ ), appearing solitary or in small groups, from February to April, in roadside verges near grasslands areas without trees, associated exclusively with Tuberaria guttata. Occurring in Southwestern Iberian Peninsula.

Specimens Examined: PORTUGAL: Alentejo: Arraiolos, 30 March 2017, C. Santos-Silva leg. (UEVH-FUNGI 2003820, GenBank: MN338729; UEVH-FUNGI 2003821, GenBank: MN338730; UEVH-FUNGI 2003840, GenBank: MN338727; UEVH-FUNGI 2003846, GenBank: MN338728); Idem, idem, Arraiolos, 14 February 2019, R. Louro leg. (UEVH-FUNGI 2004746; GenBank: MN338732); Idem, idem, Évora, 27 February 2019, R. Louro leg. (UEVH-FUNGI 2004593, GenBank: MN338733).

Remarks: Terfezia solaris-libera sp. nov. differs from other spiny-spored Terfezia species associated with Tuberaria guttata by its poor delimited thicker peridium and different sporal ornamentation, and from all Terfezia spp. in its ITS nrDNA sequence. T. fanfani usually reachs large ascocarp dimensions, often with prismatic peridium cells, with olive green tinges in mature gleba and a different sporal ornamentation. T. lusitanica has a lighter yellowish and thinner peridium and a blackish gleba upon maturity, $T$. extremadurensis has a thinner well delimited peridium and Tuber-like gleba. Exclusively associated with Cistus, Terfezia cistophila shares a similar habitat as the aforementioned species, differing from all in its spermatic odour. It can be separated from T. solaris- libera sp. nov. By its thinner peridium and smaller spores. 

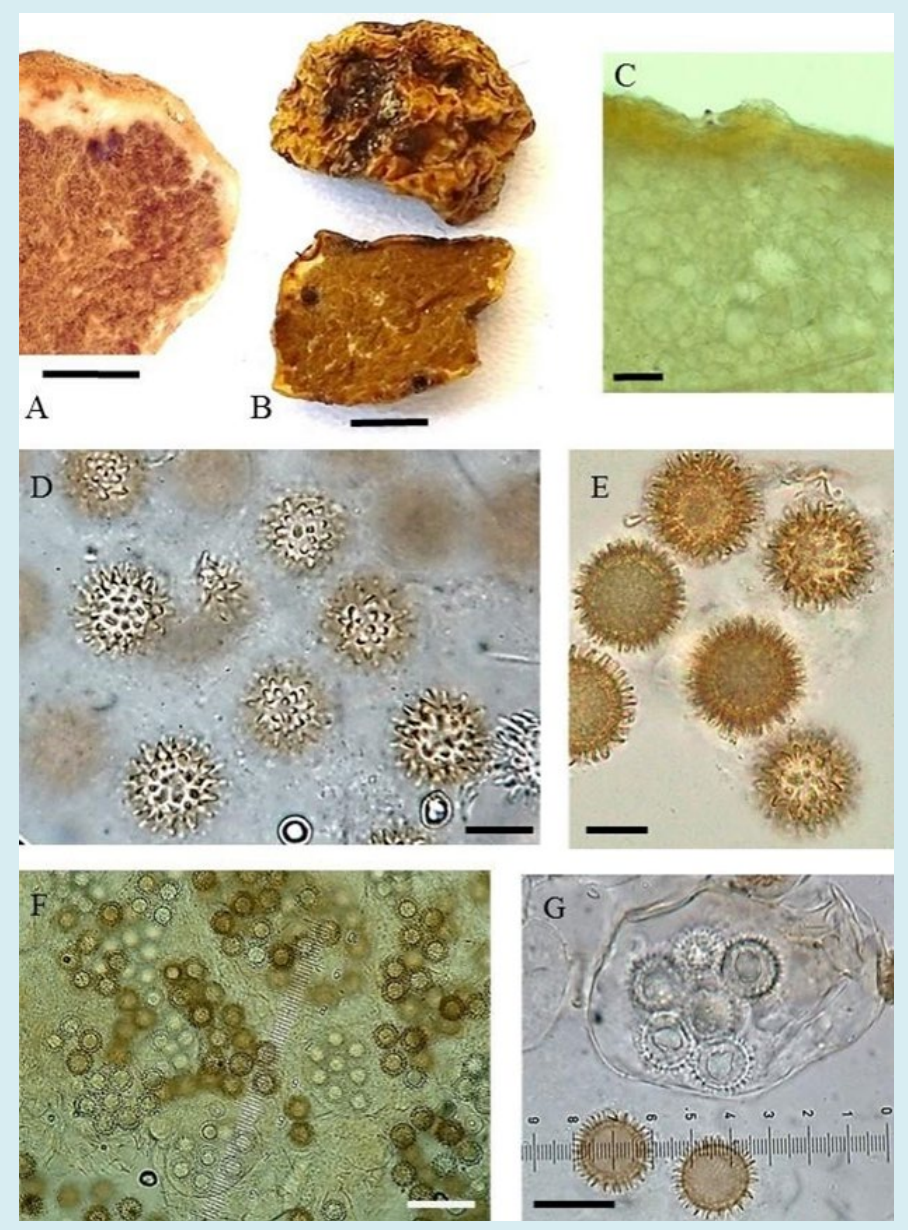

Figure 1: Terfezia solaris-libera, sp. nov.

A: Fresh Mature Ascocarp Sectioned (50mm), B: Dry Ascocarp External Peridium and Gleba (50mm), C: Detail of the Pseudoparenchymatous Peridium $(50 \mu \mathrm{m})$, D \& E: Details of Mature and Immature Spore Ornamentation Under Different Light

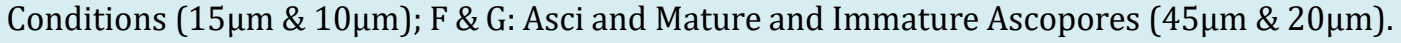

\section{Key to Examined Species}

1a. Associated exclusively with Cistus and with spermatic odor. T. cistophila

1b. Associated, mainly, with Tuberaria guttata without spermatic odor.

\section{2}

2a. Peridium with reddish colour and gleba with olive-green tinges

\section{T. fanfani}

2b. Peridium with no reddish colours and gleba with no green tinges..

3

3a. Gleba with blackish-grey pockets at maturit.

T. lusitanica

3b. Gleba with brownish pockets at maturit

T. solaris-libera sp. nov.

\section{Phylogenetic Analysis}

The reconstructed phylogeny ample supports the newly described species T. solaris-libera sp. nov. and corroborates the existence of 17 distinct clades representing well supported monophyletic groups (Figure 2). The sequence originally named T. leptoderma (GenBank accession no. AF396864) remains isolated and does not nested inside of any clade. All reconstructed phylogenies were congruent, regardless the method used (Supplemental Material 1). The clade comprising the $T$. solaris-libera $\mathrm{sp}$. nov. Sequences harbors also the Genbank sequences HM056215, HQ698132 and HQ698149 (Figure 2). The sequences referred to above belong to ascocarps collected in Spain, initially identified as Terfezia sp., T. aff. Olbiensis and T. aff. Olbiensi respectively. The other spiny-spored Terfezia species were also well supported in monophyletic groups, separating specimens of T. lusitanica, T. cistophila and T. fanfani. 


\section{Discussion}

The morphological characters of T. solaris-libera sp. nov. (Figure 1) and the ITS based phylogenetic analyses (Figure 2) provide strong support that it is a new species. $T$. solaris-libera sp. nov. Is morphologically different from other Terfezia species previously described $[6,7,13,14,36-40]$. The images here presented serve not only the species description goal but also are intended to be used as tools for mycologists dealing with morphological identification of Terfezia species. Images of the diagnosing characters referring to the gleba and peridium are presented in optical microscopy under current working conditions. Likewise, and because it is well known that maturity of the specimens is crucial for its identification, and hence care was taken to present images from both immature and mature spores (being the last ones needed for identification purposes).

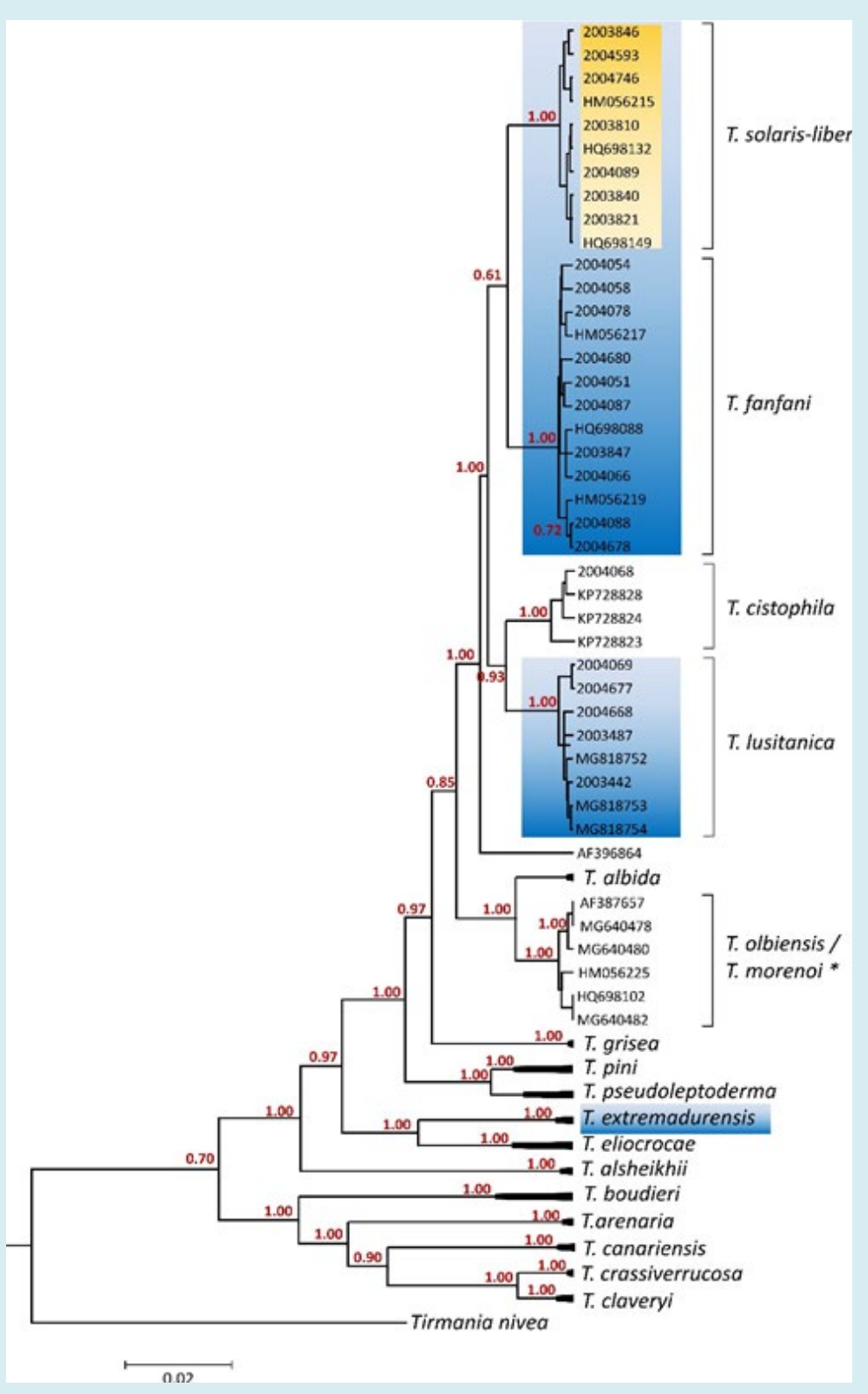

Figure 2: Phylogenetic relationship between Terfezia species. The phylogeny corresponds to the majority rule consensus tree of trees sampled in a Bayesian analysis, and the posterior probability values are shown for main nodes. (ML, ME \& NJ analyses presented in Supplemental Material 1). Newly obtained sequences are coded with the herbarium number (Table 1). Other sequence codes correspond to GenBank accession numbers (Supplemental Table 1). The spiny spore species associated with T. guttata are highlighted in blue; the new described species in orange. *clade comprising three T. olbiensis and three T. morenoi sequences. 


\section{Open Access Journal of Mycology \& Mycological Sciences}

T. solaris-libera sp. nov. Shares soil preferences and the host plant species (Tuberaria guttata) with $T$. extremadurensis, T. fanfani and T. lusitanica, but differs in morphological characteristics and phylogenetic distances. According to our experience, the species T. solaris-libera sp. nov., T. extremadurensis, T. fanfani and T. lusitanica, have never been found with other host plant different from Tuberaria guttata. These host-symbionts specificity dynamics raises several questions, particularly due to the vast polymorphism of T. guttata [31]. This host plant is characterized by high ecological plasticity and by substantial variations in the breeding system with different subspecies and varieties being recognized [32,33]. This, as recently highlighted [14], can have an impact on the specificity of the associated Terfezia species. The overall scarcity of information on the host plant of the different species of Terfezia was also recently discussed and in the case of the T. guttata the care in collecting information should go a step-forward towards the reconstruction of a co-phylogeny of host species varieties and Terfezia symbionts, disentangling eventual specificity dynamics and co-evolutionary patterns [11].

\section{Acknowledgments}

Financial support from the Project ALT20-03-0145FEDER-000006 (FEDER/FSE) is acknowledged. Tânia Nobre was supported by the "Fundacao para a Ciência e Tecnologia" (FCT- Portugal), through the research project PTDC/ASPPLA/30650/2017.

\section{References}

1. Dexheimer J, Gerard J, Leduc J, Chevalier G (1985) Etude ultrastructurale comparee des associations symbiotiques mycorhiziennes Helianthemum salicifolium-Terfezia claveryi et Helianthemum salicifolium-Terfezia leptoderma. Canadian Journal of Botany 63(3): 582-591.

2. Fortas Z, Chevalier G (1992) Effect of culture conditions on the mycorrhization of Helianthemum guttatum by three species of terfez of the genera Terfezia and Tirmania of Algeria. Canadian Journal of Botany 70(12): 2453-2460.

3. Gutiérrez A, Morte A, Honrubia M (2003) Morphological characterization of the mycorrhiza formed by Helianthemum almeriense Pau with Terfezia claveryi Chatin and Picoa lefebvrei (Pat.) Maire. Mycorrhiza 13: 299-307.

4. Morte A, Andrino A (2014) Domestication: Preparation of mycorrhizal seedlings. In: Kagan Zur V, et al. (Eds.), Desert Truffles: Phylogeny, Physiology, Distribution and Domestication. Soil Biology 38: 343-365.

5. Haouar ZFH, Fortas Z, Chevalier G (2014) Morphological characterization of mycorrhizae formed between three Terfezia species (desert truffles) and several Cistaceae and Aleppo pine. Mycorrhiza 24: 397-403.

6. Bordallo J, Rodriguez A, Munoz Mohedano J, Suz LM, Honrubia M, et al. (2013) Five new Terfezia species from the Iberian Peninsula. Mycotaxon 124: 189-208.

7. Bordallo JJ, Rodriguez A, Kaounas V, Camello F, Honrubia M, et al. (2015) Two new Terfezia species from Southern Europe. Phytotaxa 230(3): 239-249.

8. Dafri A, Beddiar A (2017) Desert truffles from northeastern Algerian coastal dunes: Ecology, identification and symbiosis. Journal of Fundamental and Applied Sciences 9(1): 153-169.

9. Honrubia M, Cano A, Molina Ninirola C (1992) Hypogeous fungi from Southern Spanish semiarid lands. Persoonia 14(4): 647-653.

10. Kovacs G, Trappe J (2014) Nomenclatural History and Genealogies of Desert Truffles. In: Kagan Zur V, et al. (Eds.), Desert Truffles: Phylogeny, Physiology, Distribution and Domestication. Soil Biology 38: 21-37.

11. Louro R, Santos Silva C, Nobre T (2019) What is in a name? Terfezia classification revisited. Fungal Biology 123(4): 267-273.

12. Bordallo JJ, Rodriguez A (2014) Cryptic and New Species. In: Kagan Zur V, et al. (Eds.), Desert Truffles: Phylogeny, Physiology, Distribution and Domestication. Soil Biology 38: 39-53.

13. Mattirolo 0 (1900) The hypogea of Sardinia and Sicily. Malpighia 14: 39-110.

14. Bordallo JJ, Rodriguez A, Santos Silva C, Louro R, Munoz Mohedano J, et al. (2018) Terfezia lusitanica, a new mycorrhizal species associated to Tuberaria guttata (Cistaceae). Phytotaxa 357(2): 141-147.

15. Bouyoucos G (1962) Hydrometer method improved for making particle size analyses of soils. Agronomy Journal 54(5): 464-465.

16. Nobre T, Gomes L, Rei F (2018) Uncovered variability in olive moth (Prays oleae) questions species monophyly. PLoS ONE 13(11): 1-12.

17. White T, Bruns T, Lee S, Taylor J, Innis M, et al. (1990) Amplification and direct sequencing of fungal ribosomal RNA genes for phylogenetics. In: Innis M, et al. (Eds.) PCR protocols: a guide to methods and applications. Academic Press, New York, pp: 315-322. 


\section{Open Access Journal of Mycology \& Mycological Sciences}

18. Katoh K, Rozewicki J, Yamada KD (2017) MAFFT online service: multiple sequence alignment, interactive sequence choice and visualization. Briefings in Bioinformatics 20(4): 1160-1166.

19. Drummond A, Rambaut A (2007) BEAST: Bayesian evolutionary analysis by sampling trees. BMC Evolutionary Biology 7: 214.

20. Kumar S, Stecher G, Li M, Knyaz C, Tamura K (2018) MEGA $\mathrm{X}$ : Molecular Evolutionary Genetics Analysis across computing platforms. Mol Biol Evol 35(6): 1547-1549.

21. Posada D (2008) J Model Test: Phylogenetic Model Averaging. Molecular Biology and Evolution 25(7): 1253-1256.

22. Diez J, Manjon JL, Martin F (2002) Molecular phylogeny of the mycorrhizal desert truffles (Terfezia and Tirmania), host specificity and edaphic tolerance. Mycologia 94(2): 247-259.

23. Kovacs GM, Balazs TK, Calonge FD, Martin MP (2011) The diversity of Terfezia desert truffles: new species and a highly variable species complex with intrasporocarpic nrDNA ITS heterogeneity. Mycologia 103(4): 841-853.

24. Dafri A, Beddiar A (2017) Desert truffles from northeastern Algerian Coasal dunes: Ecology, identification and symbiosis. J Fundam Appl Sci 9(1): 153-169.

25. Ferdman Y, Aviram S, Roth Bejerano N, Trappe JM, Kagan Zur V (2005) Phylogenetic studies of Terfezia pfeilii and Choiromyces echinulatus (Pezizales) support new genera for southern African truffles: Kalaharituber and Eremiomyces. Mycological Research 109(2): 237-245.

26. Bouzadi M, Grebenc T, Turunen O, Taib H, Alafai A, et al. (2017) Characterization of Libyan desert truffles, unpublished.

27. Sbissi I, Ghodhbane Gtari F, Neffati M, Ouzari H, Boudabous A, et al. (2011) Diversity of the desert truffle Terfezia boudieri Chatin. in southern Tunisia. Can J Microbiol 57(7): 599-605.

28. Bordallo JJ, Rodriguez A, Honrubia M, Morte A (2012) Terfezia canariensis $s p$. Nov. a new species of truffle found in the Canary Islands. Cantarella 56: 1-8.

29. Jamali S, Banihashemi Z (2012) Hosts and distribution of Desert Truffles in Iran, based on morphological and molecular criteria. J Agr Sci Tech 14(6): 1379-1396.

30. Zitouni Haouar F, Carlavilla J, Moreno G, Manjon J, Fortas Z (2018) Genetic Diversity of the Genus Terfezia (Pezizaceae, Pezizales): New Species and New Record from North Africa. Phytotaxa 334(2): 183-194.

31. Moreno G, Galan R, Ortega A (1986) Hypogeous fungi from continental Spain I. Cryptogamie Mycologie 7: 201229.

32. Nei M, Kumar S (2000) Molecular Evolution and Phylogenetics. Oxford University Press, New York, pp: 348.

33. Saitou N, Nei, M (1987) The neighbor-joining method: A new method for reconstructing phylogenetic trees. Mol Biol Evol 4(4): 406-425.

34. Felsenstein J (1985) Confidence limits on phylogenies: An approach using the bootstrap. Evolution 39(4): 783791.

35. Rzhetsky A, Nei M (1992) A simple method for estimating and testing minimum evolution trees. Molecular Biology and Evolution 9(5): 945-967.

36. Tulasne LR, Tulasne CH (1851) Fungi Hypogaei History and monograph of hypogeous fungi. Parisiis.

37. Crous P (2018) Fungal Planet description sheets 751. Persoonia 40: 324-325.

38. Gallego MJ, Aparicio A (1993) Karyological study in the genus Tuberaria sect. Scorpioides (Cistaceae): taxonomic and evolutionary inferences. Plant Systematics and Evolution 184(1): 11-25.

39. Herrera J (1992) Flower variation and breeding systems in the Cistaceae. Plant Systematics and Evolution 179: 245-256.

40. Gallego M (1993) Xolantha Raf. In: Castroviejo S, et al. (Eds.), Flora Iberica 3, Real Jardin Botanico, CSIC Madrid, pp: 351-365.

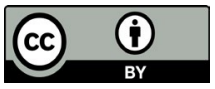

